\title{
ISLAM, POPULISME DAN MASA DEPAN DEMOKRASI DI INDONESIA
}

\author{
Syamsul Arifin
}

\begin{abstract}
Abstrak
Populisme merupakan konsep yang disematkan pada gerakan Islam di Indonesia belakangan ini mengiringi beberapa rangkaian politik elektoral baik di level lokal maupun nasional. Ihwal penyematan ini dilatarbelakangi oleh penggunaan identitas keagamaan yang mengesankan gerakan yang dirancang oleh beberapa elite dari kalangan Islam merupakan gerakan eksklusif. Gerakan ini untuk sementara waktu membuahkan hasil yang ditunjukkan dengan kemenangan salah satu pasangan dalam Pilkada di DKI Jakarta pada 2017. Sukses dalam politik elektoral, gerakan populisme Islam terus dirawat yang nantinya menjadi suatu strategi permanen dalam kontestasi politik elektoral di tingkat nasional. Populisme Islam bagi sebagian kalangan dikhawatirkan dapat menghalangi perkembangan demokrasi di Indonesia yang sejatinya masih dalam proses transisi menuju konsolidasi demokrasi. Artikel ini pertama-tama ingin memberikan apresiasi terhadap kontribusi umat Islam sebagai kelompok keagamaan terbesar di Indonesia karena telah memberikan contoh yang baik bagi negara-negara mayoritas Islam lainnya dalam mentransformasi rezim otoriter ke rezim yang lebih demokratis. Pembahasan berikutnya ingin meletakkan populisme sebagai suatu gerakan yang seharusnya memberi manfaat positif terhadap perkembangan demokrasi di Indonesia mengingat pandangan Muslim mainstream menerima demokrasi baik sebagai suatu fakta sejarah maupun karena dari sisi teologis, Islam dan
\end{abstract}


demokrasi tidak perlu diletakkan dalam posisi yang saling berhadapan.

Kata Kunci : Islam, Populisme, Demokrasi, Politik Elektoral, Pemilu

\section{Pengantar}

Pemilihan Umum (Pemilu) 2019, baik menjelang pelaksanaannya pada 17 April, maupun pada hari " $\mathrm{H}$ ", serta sesudahnya, diiringi oleh berbagai peristiwa yang menarik dikaji secara lebih mendalam. Setahun jelang Pemilu 2019 yang perhatian publik rupanya lebih mengerucut ke pemilihan presiden, dilakukan pemilihan kepala daerah secara serentak di 171 wilayah, termasuk 17 provinsi. Perhelatan akbar tersebut disebut oleh Majalah Tempo dalam edisi 25 Juni-1 Juli 2018, serasa pilpres dan sekaligus sebagai pemanasan terakhir. Pembingkaian semacam itu bukan saja karena besarnya jumlah pemilih yang mencapai 152 juta pemilih yang berarti mendekati 80\% dari sekitar 196 pemilih di seluruh Indonesia, tetapi karena pemenang pada pilkada terutama di wilayah-wilayah dengan jumlah pemilih terbesar seperti Jawa Barat, Jawa Timur, Jawa Tengah, dan Sumatera Utara, ikut menjadi penentu pemenangan pilpres yang akan dihelat pada tahun berikutnya.

Sebagaimana pada momen politik elektoral yang terjadi setahun sebelumnya, Pilkada 2017, terutama yang berlangsung di DKI Jakarta, Pilkada 2018 dan berikutnya Pemilu 2019, terjadi pembelahan warga baik yang memiliki hak memilih maupun yang belum, karena kian menguatnya sentimen etnis dan agama menyusul insiden pidato Basuki Tjahaja Purnama atau Ahok mengenai al Maidah 51. Pembelahan ini tidak bisa dianggap sebagai fenomena sederhana karena terbukti menggerus rasionalitas publik yang pada gilirannya menciptakan suatu realitas apa yang disebut dengan masyarakat pascakebenaran (post-truth society). Dalam realitas ini, teori kebenaran korespondensi (the correspondence theory of thruth) yang mendalilkan bahwa kebenaran karena adanya kesesuaian antara pernyataan dan kenyataan, tidak berlaku. Alih-alih kenyataan, justru pernyataan yang lebih dikedepankan yang secara terus-menerus dialirkan melalui berbagai media sosial sehingga diterima sebagai sebuah kebenaran, kendati sama sekali tidak didukung oleh fakta, atau yang populer dengan sebutan hoaks. Sebaliknya, kendati didukung dengan fakta yang memadai, sulit diterima sebagai kebenaran. 
Beberapa saat setelah pencoblosan Pemilu 2019, banyak lembaga survei yang mengumumkan hasil penghitungan cepat (quick count) yang dengannya publik bisa memprediksi pihak-pihak yang unggul, entah pemilihan presiden, DPD, DPR RI dan DPRD. Perhitungan cepat sejatinya mendekati hasil perhitungan yang sesungguhnya (real count). Di luar kepentingan memprediksi hasil pemilu, quick count juga mengandung pembelajaran kepada publik, di antaranya di samping mencegah terjadinya kecurangan penghitungan oleh lembaga yang memang diberi mandat penuh sebagai penyelenggara pemilu, yaitu Komisi Pemilihan Umum (KPU), juga pihak-pihak yang terlibat dalam pemilu segera menyiapkan sikap yang menunjukkan kedewasaan, entah siap kalah atau siap menang. Sayangnya hasil quick count alih-alih diterima, justru banyak kalangan utamanya dari para elite yang mengembangkan narasi kebencian (hate speech) kepada lembaga-lembaga survei. Narasi sejenis bahkan tidak hanya ditujukan kepada lembaga-lembaga survei tetapi juga tertuju kepada KPU yang dituduh melakukan kecurangan saat rekapitulasi suara Pilpres 2019. Narasi yang tidak disertai dukungan data yang kuat, terbukti kian memperkeruh ketegangan yang berpotensi menimbulkan konflik horizontal dan vertikal secara lebih terbuka.

Beragam peristiwa yang menyertai pelaksanaan Pemilu 2019, memberikan pelajaran berharga (lesson learned) betapa proses untuk sampai ke tahapan ideal demokrasi, yaitu konsolidasi demokrasi, masih memerlukan ikhtiar dan waktu yang lumayan panjang. Demokrasi di Indonesia, sebagaimana di negaranegara lain yang masuk dalam kategori negara demokratis, sebenarnya telah memerhatikan elemen-elemen penting dalam demokrasi yang berlaku secara universal seperti disebut ilmuwan politik dari Stanford University, Larry Diamond (Neheer Dasandi, 2018: 12-13), yang menyebut empat komponen dasar (four basic elemements) demokrasi, yaitu: "competetion for power, whereby governments are chosen and replaced through free and fair elections; active participan of the people, as citizens, in politics and civic life; protection of the basic human rights of all citizens; and the rule of law, in which the laws and procedures apply equally to all citizens."

Meskipun demikian, banyak dari kalangan elite dan akademisi di Indonesia yang menyadari bahwa demokrasi merupakan sistem yang tidak gampang diterapkan apalagi dengan capaian, alih-alih sekedar mendekati sempurna, karena adanya pengaruh dari berbagai variabel seperti perjalanan sejarah Indonesia, serta nilai-nilai budaya yang hidup, dan keyakinan yang dianut masyarakatnya (Zulkifli Hasan, 2019). Pengaruh dari variabel sejarah dan budaya suatu bangsa mengakibatkan penerapan demokrasi tidak bisa homogen, 
tetapi menggunakan berbagai model, di antaranya adalah model "the third world democracy" seperti disebut Andrew Heywood. Praktik demokrasi di negara yang disebut Andrew Heywood masih jauh dari ideal. Tulis Andrew Heywood (1992: 288) "The danger of Third World democracy is that in absence of competetive election the charismatic leader and ruling party may become corrupt, serving their own interests rather than those of society at large."

Sejarah demokrasi di Indonesia mendekati gambaran Andrew Heywood. Peralihan dari Orde Lama ke Orde Baru ditandai dengan penyederhanaan partai politik sebagai kebijakan ikonik di bidang politik yang dikeluarkan oleh Soeharto pada awal-awal kekuasannya. Pada Pemilu 1955, pemilu pertama para era Presiden Soekarno, partai politik yang bertarung mencapai 172 partai untuk memilih anggota DPR dan Konstituante. Pemilu 1955 disebut pemilu paling demokratis kendati kondisi keamanan di Indonesia diliputi ketidakpastian. Pada 1971 diselenggarakan pemilu pertama pasca-Orde Lama yang diikuti oleh 10 partai. Tetapi pada Pemilu 1977 partai yang ikut serta hanya tiga menyusul kebijakan penyederhanaan partai politik untuk menciptakan stabilitas politik sebagai prasyarat pembangunan ekonomi yang menjadi prioritas presiden Soeharto. Di samping terjadi fusi beberapa partai politik: NU, Parmusi, PSII dan PERTI bergabung menjadi Partai Persatuan Pembangunan (PPP), lalu muncul Partai Demokrasi Indonesia (PDI) sebagai fusi dari PNI, Partai Katolik, Partai Murba, IPKI, dan Parkindo, pasca-fusi partai politik dilaksanakan pemilu hingga lima kali yang selalu ditandai dengan dua keberhasilan, pertama, kemenangan Golkar yang mengantarkan dan kian mengukuhkan-sebagai keberhasilan yang kedua-Soeharto sebagai presiden terlama dalam sejarah kepresidenan di Indonesia. Sebagaimana dikatakan Andrew Heywood, pada zaman Orde Baru pemilu dilaksanakan secara periodik setiap lima tahun, pada kenyataannya pemilihan yang kompetitif (competitive election) tersebut tidak pernah terjadi, karena itu Golkar selalu menjadi ruling party yang menjadi salah satu pilar yang kokoh untuk keberlangsungan Soeharto sebagai presiden, tidak saja sebagai pemimpin kharismatik, bahkan tidak sedikit dari kalangan akademisi yang menyebutnya otoriter (Richard Robinson, 1986; Julie Southwood and Patrick Flanagan, 1983; Donald K. Emmesrson, 2001; Douglas E. Ramage, 2005).

Tahapan yang sedang dilakoni oleh bangsa Indonesia pada saat ini baru transisi demokrasi setelah sebelumnya, dua dekade lalu, berhasil melalui tahapan krusial yang disebut dengan regime breakdown. Bukan pekerjaan gampang mengakhiri rezim lama yang memiliki rajutan begitu kuat yang melibatkan dua instrumen kenegaraan, yaitu ideological state apparatus dan repressive state apparatus, kendati 
pada akhirnya bisa ditumbangkan (regime breakdown) oleh gelombang gerakan masyarakat sipil (civil society).

Pada tahapan berikutnya, transisi, terjadi pergeseran dan pengembangan kepranataan yang bisa menjamin pergantian suatu rezim secara kompetetif melalui penyelenggaraan pemilihan umum yang terbuka. Setelah Pemilu 1999, pemilu pertama pasca-Orde Baru, terjadi perubahan paradigma terkait dengan penyelenggaraan pemilu terutama presiden. Pada pemilu-pemilu berikutnya, 2004, 2009, 2014, dan 2019, pemilihan presiden dilakukan secara langsung.

Sukses dengan penyelenggaraan Pemilu 2004, Indonesia memeroleh apresiasi dari dunia yang antara lain tertuju kepada kalangan Muslim sebagai kelompok mayoritas-Indonesia disebut sebagai negeri Muslim demokratis terbesar di dunia pasca-Pemilu 2004. Di negara-negara di mana Islam dipeluk secara mayoritas selalu disikapi dengan penuh keraguan oleh beberapa akademisi karena baik secara kultural maupun ekonomi dipandang tidak memiliki basis yang kuat yang dapat menjamin tegaknya demokrasi. Beberapa hari setelah Pemilu 2004, Jimmy Carter, presiden ke-39 Amerika Serikat (1977-1981) memberikan apresiasi sebagaimana ditulis International Herald Tribune (edisi 15 Juli 2004), "A milestone for us, this election also was a significant step forward for democracy worldwide. The people of Indonesia are providing a dramatic example of peaceful political change, and firmly negating the claim that Muslim societies are anti-democratic. It is interesting to note that, of the world's three largest democracies, the overwhelming majority of their populations have different religious faiths: Hindus in India, Christians in the United States and Muslims in Indonesia. This is a good message for Americans to absorb."

Sebagai perbandingan antara Indonesia dengan negara-negara di mana Islam sebagai mayoritas, hasil survei Freedom House, organisasi nirlaba yang berpusat di Washington, D.C, bisa dijadikan rujukan. Setahun sebelum pelaksanaan Pemilu 2004, Freedom House menyelenggarakan survei terkait kebebasan sipil (civil liberties) dan akomodasi hak-hak sipil (political rights) di 192 negara. Hasil survei Freedom House ini kemudian diolah oleh Majalah Gatra sebagaimana bisa dibaca kembali dalam versi publikasi buku bertajuk, Hajatan Demokrasi: Potret Jurnalistik Pemilu Langsung Simpul Islam Indonesia Dari Moderat Hingga Garis Keras (2006). Hasil survei Freedom House yang diolah oleh Asrori S. Karni memberikan gambaran memprihatinkan, karena dari 47 negara mayoritas Muslim, hanya ada dua negara yang masuk dalam kategori free (bebas), yakni Mali dan Senegal yang bertetangga dan sama-sama dijajah oleh Perancis. Sedangkan 
Indonesia bersama 16 negara lainnya berada di peringkat sebagai negara semi bebas (partly free). Selebihnya, yakni sebanyak 28 negara, antara lain Aljazair, Mesir, Arab Saudi, Iran, Afghanistan, dan Pakistan, dikelompokkan sebagai negara tidak bebas (not free). Survei Freedom House memberikan pembenaran terhadap pengakuan yang terlontar dari kalangan akademisi Muslim sendiri antara lain ditulis Tariq Ramadhan, cucu Hassan al Banna, pendiri Ikhwanul Muslimin, dalam Islam: The Essensialist (2017: 229), "The absence of freedom is also a common feature of most the Muslim-majority societies of Africa, the Middle East and Asia" Sementara apresiasi Freedom House terhadap Indonesia kian meningkat. Pada 2013, Indonesia seperti diungkap Francis Fukuyama (2015), peringkat kebebasannya mencapai 2,5 (pada skala yang dari 1, yang terbaik, ke 7, yang terburuk).

Pemilu yang dilaksanakan sebanyak lima kali jika yang dihitung hanya pemilihan presiden secara langsung, atau enam kali jika ditambahkan dengan Pemilu 1999, seharusnya menjadi bahan pembelajaran berharga bagi bangsa Indonesia untuk mendewasakan terutama demokrasi elektoral, baik secara prosedural maupun substansial. "Sukses tiga kali pemilu dalam setahun: legislatif (5 April 2004), presiden putaran pertama (5 Juli 2004), dan presiden putaran kedua (20 September 2004)," tulis Asrori S. Karni dalam pengantar buku tersebut, "adalah prestasi politik putra-puteri bangsa yang patut dihargai-negara muslim, Indonesia justru menuai panen raya demokrasi. Hanya dalam tempo enam tahun, transisi dari rezim otoriter mampu dilewati secara mengesankan," lanjut Asrori S. Karni.

\section{Momentum Konsolidasi}

Pada kenyataannya, momentum transisi setelah terjadinya regime breakdown belum dimanfaatkan secara bijak terutama oleh kalangan elite untuk melakukan konsolidasi sehingga bisa terkristalisasi berbagai kepentingan yang dapat menekan konflik laten menjadi konflik manifes, dan mengurangi secara signifikan jika tidak bisa dihilangkan sama sekali praktik lancung berupa politik uang yang selalu melibatkan para elite dalam berbagai modus. Posisi elite menjadi salah satu perhatian dalam kajian demokrasi. Larry Diamond merupakan salah satu ahli yang menaruh perhatian besar terhadap elite dalam konsolidasi. Ditegaskan oleh Larry Diamond, konsolidasi demokrasi meniscayakan suatu komitmen mutual di kalangan elite yang dilakukan lewat mekanisme koordinasi sebuah konstitusi, institusi politik terkait dan membangun pakta kesepakatan tanpa memperdulikan partai atau faksi yang mengontrol negara 
dalam waktu tertentu. Ditegaskan pula oleh Larry Diamond, elite sebaiknya tidak menggunakan retorika yang mengandung hasutan dan mendorong pengikutnya melakukan tindakan-tindakan yang bertentangan dengan hukum (Sutoro Eko, 2003). Konsolidasi memang terjadi, tetapi lebih didorong untuk menciptakan suatu aliansi terbatas yang kemudian terbentuk kartel dan oligarki seperti diungkap oleh beberapa akademisi antara lain oleh Kuskrido Ambardi dalam Mengungkap Politik Kartel (2009).

Publikasi yang berasal dari disertasi The Ohio State University, itu mengungkap ihwal kartelisasi yang dilatarbelakangi keterbatasan sumber keuangan parpol, maka untuk menutupinya mereka berburu uang pemerintah di luar yang sudah dialokasikan kepada parpol, melainkan uang pemerintah melalui perburuan rente (rent-seeking). Aktivitas ini, jelas dosen UGM itu, hanya dimungkinkan jika mereka memiliki akses dalam jabatan pemerintahan dan parlemen, lebih khusus lagi, jabatan menteri dan parlemen di tingkat komisi untuk memelihara sumber keuangan parpol.

Karena itu menyoal ideologi parpol yang terlibat dalam proses kartelisasi menjadi tidak relevan. Analisis terkait pembelahan atau clevage parpol dilihat dari sisi ideologi, sepertinya hanya cocok untuk mengetahui histori pembentukan partai yang didasarkan pada ideologi tertentu yang dalam kasus di Indonesia pembelahannya terlihat begitu longgar: nasionalis dan religius, atau gabungan keduanya, nasionalis-religius.

Pembelahan parpol yang begitu longgar, memudahkan beberapa parpol membentuk aliansi, tetapi alih-alih didasarkan pada ideologi, namun lebih banyak didasarkan pada kesamaan kepentingan yang lebih bersifat pragmatis. Kian menarik jika aliansi parpol dicermati dalam konteks politik elektoral di level regional dan lokal. Kendati pada tingkat nasional seperti pada Pemilu 2019 yang lalu, misalnya antara PKB dan PAN berada dalam kubu yang saling berlawanan, sangat mungkin terjadi hal sebaliknya pada pemilu kepala daerah (gubernur, bupati, dan walikota). Yang menarik pula, parpol non-religius, bisa melakukan positioning sebagai parpol yang ingin mengadvokasi kepentingan kelompok agama tertentu.

Karena alih-alih kepentingan daripada ideologi, tidak sedikit terutama dari kalangan elite yang ada di parpol dengan di pemerintah dan parlemen merancang konspirasi melakukan perburuan rente (rent-seeking) dengan berbagai modus seperti pemberian-pemberian pribadi (individual gift), pelayananpelayanan aktivitas (services and activities), barang-barang kelompok (club goods), 
proyek-proyek gentong babi (pork barrel projects) seperti ditulis Edward Aspinal dan Mada Sukmajati (2015), yang sebagian hasilnya masuk ke kantong elite, sebagian yang lain sangat mungkin digunakan untuk operasional parpol. Pada 2015, publik di tanah air dihebohkan dengan kasus PT Freeport Indonesia 2015 atau yang populer juga dengan sebutan kasus "Papa Minta Saham” yang melibatkan antara lain Setya Novanto yang memiliki posisi ganda yang sangat strategis: Ketua DPR RI dan Ketua Umum Partai Golkar. Tidak hanya kasus ini, Setya Novanto juga terjerat kasus KTP Elektronik. Kasus berikutnya yang melibatkan petinggi parpol dengan modus konspirasi yang kurang lebih sama, dilakukan oleh Romahurmuziy (mantan Ketua Umum PPP) dengan beberapa pejabat di Kementerian Agama. Dua kasus ini melengkapi kasus sebelumnya yang lagi-lagi melibatkan petinggi parpol seperti dilakukan Luthfi Hasan Ishaaq dalam kasus suap daging sapi impor pada awal 2013.

Ketiga kasus tersebut sekedar contoh di puncak gunung es. Dikatakan demikian karena korupsi, ditambah kolusi dan nepotisme (KKN) yang menjadi sasaran dari gelombang aksi masyarakat sipil yang diharapkan bisa digerus dengan demokratisasi, justru demokrasi kita, seperti diingatkan oleh Romo Franz Magnis-Suseno (2014), dalam keadaan bahaya karena malah menyuburkan praktik korupsi. Mohammad Mahfud MD menyuarakan hal yang sama. Pada pengantar buku Burhanuddin Muhtadi, Populisme Populitik Identitas EF Dinamika Elektoral (2019), ahli hukum tata negara, ini mengatakan, “... gagalnya demokrasi mengalahkan demokrasi korupsi di Indonesia disebabkan oleh karena reformasi sudah berbelok dari jalan demokrasi ke jalan oligarki."

Elite tidak hanya bertanggung jawab terhadap kegagalan demokrasi di Indonesia sebagaimana disuarakan oleh dua tokoh di atas, tetapi harus bertanggung jawab pula terhadap kian menjauhnya demokrasi kita dari keadaban publik lainnya, yaitu pembelahan dan ketegangan yang pada gilirannya menciptakan konflik vertikal dan horizontal seperti terjadi pada 22 Mei yang lalu. Penulis telah lama beralih dari cara pandang primordialist view ke instrumentalist view dalam menganilisis konflik. Cara pandang pertama, cenderung mempersalahkan keragaman sebagai penyebab konflik. Ada banyak tempat di bawah kolong langit ini yang justru terjadi relasi secara damai (coexistence) kendati ditandai keragaman. Kalau toh terjadi konflik, biasanya karena ulah para elite seperti diungkap oleh cara pandang yang kedua, instrumentalist view (Syamsul Arifin, 2015). Dengan mengemukakan cara pandang instrumentalist dimaksudkan untuk mempertegas bahwa konflik alih-alih sebagai peristiwa alamiah biasa, melainkan karena rekayasa atau diciptakan oleh elite. 
Rusuh 22 Mei yang lalu, seharusnya tidak perlu terjadi jika elite politik kita mampu melakukan konsolidasi dalam arti yang sesungguhnya seperti diurai oleh Grame Gill dalam The Dynamic of Democratization: Elites, Civil Society and the Transition Process (2000: 8), "Concolidation is when those structures and process have become stabilized and embeded in the collective consciousness of the society that they gain normative authority."

\section{Populisme Populitik Identitas Keagamaan: Populisme Islam}

Konflik yang terjadi pasca-Pemilu 2019 mengindisikasikan demokratisasi di Indonesia baru sebatas prosedural, yang tahapan ini juga masih diwarnai dengan sengkarut tata kelola, sementara demokrasi dalam arti substansial masih jauh dari ideal. Dikatakan mendekati ideal, bila demokrasi kita dibingkai oleh apa yang disebut Robert W. Hefner (1998) dengan democratic civility, yaitu demokrasi yang tegak antara lain di atas nilai-nilai toleransi supaya politik elektoral terhindari dari chaos. Jika keadaban demokrasi ini belum bisa ditegakkan, kita khawatir demokrasi kita bisa berakhir mengenaskan seperti judul beberapa buku yang terbit belakangan ini, di antaranya Is Democracy Failing? (2018), How Democracy Ends (2018), dan How Democracies Die (2018).

Elite tentu memiliki modal, baik terlihat (tangible) maupun yang tidak terlihat (intangible). Modal yang terlihat berbentuk materi, terutama uang. Sedangkan yang tidak terlihat tetapi seringkali memiliki efek lebih dahsyat daripada materi, penting disebut adalah kemampuan elite dalam mengonstruksi suatu gagasan retoris yang memengaruhi emosi massa. Belakangan konsep populisme sering dipakai oleh beberapa akademisi di tanah air, misalnya Vedi R. Hadiz dan Burhanuddin Muhtadi, untuk menjelaskan menguatnya politik identitas utamanya pada diri umat Islam yang pada momen tertentu berhasil menciptakan solidaritas yang diarahkan pada pencapaian politik elektoral, kendati di sisi lain ikut memperkeruh pembelahan bahkan di kalangan umat Islam sendiri yang pada gilirannya menimbulkan konflik.

Dalam bagian pengantar publikasi bukunya versi terjemahan ke dalam bahasa Indonesia, Populisme Islam di Indonesia dan Timur Tengah (2019), Vedi R. Hadiz coba mengaitkan aksi di Jakarta pada 4 November 2016 dan 2 Desember 2016-belakangan dikenal dan dikenang dengan sebutan aksi 411 dan 212sebagai momentum kebangkitan populisme Islam di Indonesia, sebagaimana pula pembacaan akademisi dari LIPI, Wasisto Raharjo Jati, dalam artikel yang 
dipublikasikan oleh Prisma Volume 36, Nomor 3, 2017, Trajektori Populisme Islam di Kalangan Kelas Menengah Muslim Indonesia. Tulisnya, "Membincangkan populisme dalam Islam merupakan narasi dan analisis yang menarik dalam kajian sosial politik Indonesia dewasa ini." Hal tersebut kian "mengental" dengan berlangsungnya serangkaian aksi protes massal jalanan (mobocracy) saat pemilihan Gubernur DKI Jakarta 2017 silam yang mengatasnamakan "Aksi Bela Islam”, “Aksi Bela Qur'an”, serta “Aksi Bela Ulama” dengan menggunakan tagar \#Aksi411 dan \#Aksi212. Azyumardi Azra (2019) juga menunjuk pemilihan Gubernur DKI Jakarta 2017 sebagai momentum menguatnya populisme Islam sekaligus identitas Islam di Indonesia. Fenomena kontemporer di Indonesia seakan membenarkan pernyataan Kwame Anthony Appiah (2018:3) "Untill the middle of twentieth century, no one who asked about a person's identity would have mentioned race, sex, class, nationality, region, or religion... Identity here is utterly particular and personal. The identities we think of today, on the other hand, are shared, often, with millions or billions of others. They are social," Dari yang pada mulanya bersifat personal seperti dikemukakan Appiah, identitas menurut Francis Fukuyama dalam Identity (2018), mendasari berbagai fenomena politik kontemporer, mulai dari gerakan nasionalis populisme baru hingga gerakan yang dirancang oleh sebagian umat Islam.

Proses tersebut tentu tidak berlangsung secara tiba-tiba dan lewat mekanisme yang biasa-biasa, misalnya sekedar hubungan antarpersonal sehari-hari (interpersonal relationships) yang alamiah seperti dikemukakan Helen SpencerOatey dan Peter Franklin (2009), tetapi karena kemampuan kalangan elite dalam mengolah identitas sehingga menjadi kekuatan kolektif yang didasari kepentingan tertentu yang pada umumnya bersifat politik. Kendati tidak mudah didefinisikan seperti dikemukakan Burhanuddin Muhtadi, tetapi menariknya, diperebutkan, seperti ditulis Jan-Werner Muller (2018), serta merujuk pada konteks yang berbeda dengan berbagai fenomena yang membingungkan seperti dikatakan Margaret Cannovan (1981), populisme digunakan sebagai konsep untuk menjelaskan fenomena sosial politik kontemporer yang ditandai dengan menguatnya identitas, yang dalam konteks fenomena kontemporer umat Islam di Indonesia, identitas tersebut lebih ditekankan pada aspek keagamaan bahwa meskipun Islam sebagai agama yang dipeluk secara mayoritas, tetapi di sisi lain dikonstruksi sebagai kelompok yang terpinggirkan.

Konstruksi sebagai kelompok yang terpinggirkan bisa dipahami sebagai salah satu cara bereaksi terhadap kondisi umat yang dirasakan sedang dilanda krisis yang serius, suatu kondisi yang juga sering disuarakan oleh kaum populis 
seperti diungkap Paul Taggart (2000). Dikatakan dikonstruksi karena pada setiap gerakan yang melibatkan massa sedemikian banyak sebagaimana terlihat dalam serangkaian aksi di Jakarta pasca-insiden al Maidah 51, selalu ada pihak yang mengapitalisasi suatu peristiwa yang dalam studi yang dilakukan Rangga Kusumo dan Hurriyah (2018) disebut dengan aktor atau elite. Mempertemukan berbagai kelompok dalam Islam yang memiliki latar belakang paham keagamaan serta basis material yang berbeda dalam suatu aliansi yang kemudian melahirkan gerakan kolektif secara berantai, tidak mudah dilakukan kecuali oleh elite.

Dimensi populis pada gerakan populisme Islam adalah terletak pada penggunaan kata umat yang dibingkai dengan deskripsi sebagai kelompok yang terpinggirkan. Dengan demikian, kata "umat” menurut Vedi R. Hadiz (2016) merupakan proksi untuk "rakyat", pihak yang sering disebut dalam gerakan populisme pada umumnya, dan (rakyat) diposisikan sebagai pihak yang sengaja dimarginalkan oleh elit yang korup (the corrupt elite) sebagaimana definisi populisme dari Cas Mudde (Daniel Stockemer, 2019) "Populism is an ideology that considers society to be ultimately separated into two homogeneous and antagonistic groups, the pure people versus the corrut elite, and which argues that politics should be an exptression of the general will of the people."

Salah satu pertanyaan yang sering terlontar dari kalangan akademisi adalah implikasi populisme terhadap masa depan demokrasi; apakah populisme akan memperkuat demokrasi, atau sebaliknya, sebagai ancaman terhadap masa depan demokrasi. Kembali mengutip Burhanuddin Muhtadi, populisme oleh sebagian akademisi dipandang sebagai pertanda yang baik karena dapat menjadi pengingat atau alarm bagi elite yang sedang berkuasa agar selalu memperhatikan kepentingan publik dalam setiap pembuatan kebijakan. Sebaliknya, populisme oleh akademisi lainnya dinilai tidak lebih sebagai suatu retorika elite untuk meraih dukungan massa yang melimpah pada momen politik elektoral tertentu. Pertanyaan yang sama tertuju kepada gerakan populisme Islam di Indonesia. Jika pertanyaannya demikian, maka perlu suatu eksplorasi terhadap kondisi umat Islam di Indonesia yang dapat memberi penguatan terhadap masa depan demokrasi, dan sebaliknya kondisi yang justru memperlemah. 


\section{Moderasi Islam bagi Masa Depan Demokrasi}

Sampai pada bagian ini, penulis ingin mengajukan tesis bahwa populisme Islam yang menguat kembali belakangan ini sejatinya bisa dikapitalisasi sebagai kekuatan yang bisa mendinamisasi demokrasi hingga ke tahapan setidaknya mendekati ideal. Dengan demikian tulisan ini ingin menempatkan populisme secara positif, bukan sebagai ancaman terhadap demokrasi, kendati tetap memberikan ruang untuk mengartikulasikan sikap kritis kepada populisme. Sikap demikian dipilihkan atas pertimbangan sosiologis dan historis posisi Islam, sebagaimana disinggung beberapa kali pada pembahasan di atas merupakan agama yang dipeluk oleh sebagian besar penduduk di Indonesia.

Tidak hanya terbatas di dalam negeri, populasi Muslim di Indonesia bahkan belum bisa ditandingi oleh negara-negara mayoritas Islam setidaknya hingga 2030 dengan catatan prediksi Pew Research Center terbukti. Dalam publikasi bertajuk The Future of the Global Muslim Population, Pew Research Center di samping membuat proyeksi ihwal perkembangan populasi Muslim di dunia yang diperkirakan terjadi peningkatan sebanyak 30\% pada 2030 sehingga yang semula pada 2010 berjumlah 1,2 milyar, akan bertambah menjadi 2,2 milyar pada 2030, juga memperkirakan terjadinya perubahan urutan negaranegara Muslim mayoritas, di mana Indonesia menempati urutan teratas dengan populasi Muslim sebanyak 204.847.000 pada 2010, di bawahnya adalah Pakistan yang memiliki populasi Muslim sebanyak 178.097.000. Tetapi pada 2030 diperkirakan terjadi pergeseran; Pakistan menempati urutan pertama dengan populasi Muslim sebanyak 256.117.000, sementara populasi Muslim di Indonesia berjumlah 238.833.000. Dengan populasi yang begitu besar dengan sendirinya Muslim di Indonesia selalu menjadi sasaran harapan peran (role expectation) supaya memosisikan sebagai kelompok strategis dalam berbagai aspek.

Kebesaran Muslim di Indonesia dari sisi angka, merupakan proses yang panjang. Para ahli sejarah Islam berdebat ihwal muasal dan permulaan kedatangan Islam ke bumi Nusantara, seperti terekam antara lain dalam kajian kesarjanaan yang dihasilkan oleh Azyumardi Azra (1994). Kendati terdapat diskursus pada bagian tersebut, ada satu bagian yang disepakati oleh semua ahli, yakni cara penyebaran Islam ke tanah air sehingga berbuah manis dalam wujud kebesaran jumlah. Alih-alih penaklukan (conquest) atau penetrasi paksa (penetration violence) yang berakibat pada terjadinya konflik berkepanjangan yang bahkan berdarah-darah dan aksi balas dendam dari orang-orang taklukan, Islam datang ke sini dengan 
cara yang damai (penetration pasifique) yang diaktori antara lain oleh kalangan pedagang.

Penetrasi secara damai, di samping relatif tidak menimbulkan ketegangan dan gejolak, keberterimaan Islam sebagai "agama baru” lebih mudah terjadi, dan demikian populasi terus bertambah, di samping karena menguatnya faktor fertilitas. Hingga kini, populasi Muslim di Indonesia nyaris mendekati 90\% dari total penduduk Indonesia yang mencapai sekitar 269 juta.

Penelusuran terhadap historitas Islam di Indonesia kendati hanya sebentar dan baru di level permukaan, bisa dijadikan bukti bahwa karakter Islam di Indonesia adalah moderat atau wasatiyyah, seturut dengan karakter Islam sendiri. Islam, tegas Yusuf Qardhawi, dalam Islam Jalan Tengah (2017) mengajak ke jalan tengah dan melarang berbuat melampaui batas atau berlebihan dalam beragama (tatharruf). Pernyataan Yusuf Qardhawi bersambung dengan pandangan Muhammad Hashim Kamali dalam The Middle Path of Moderation in Islam: The Qur'anic Principle of Wasatiyyah (2015), "Moderation is an aspect, in its Qur'anic projections, of the self-identity and worldview of the Muslim community, or ummah..."

Karakter moderat atau wasatiyyah penting terus dipelihara sebagai kesadaran kolektif Muslim di Indonesia karena nantinya akan menjadi ikatan keadaban (bond civility) dalam menghadapi keragaman di tubuh Muslim sendiri, maupun keragaman dari pihak lain, serta tantangan kekinian yang krusial. Sebab kalau ikatan keadaban ini tergerus, Muslim di sini sulit mengapitalisasi dirinya menjadi kekuatan dunia pada saat negeri-negeri Muslim yang berada di posisi pusat (centre) terjatuh pada kubangan konflik berkepanjangan baik karena perbedaan keyakinan maupun karena dipicu oleh perbedaan kepentingan ekonomi-politik.

Sebelum kepentingan ekonomi politik mengganggu, pada diri Muslim, di wilayah mana pun tinggal, terdapat faktor laten yang sewaktu-waktu akan muncul ke permukaan dalam wujud ketegangan dan konflik. Ada satu konsep yang sering digunakan untuk mengurai sengkarut relasi internal Muslim termasuk di Indonesia, yaitu unity in deversity (kesatuan dalam keragaman).

Pada awalnya Islam berasal sari sumber yang sama dengan doktrin yang sama pula terutama pada aspek yang bersifat fundamental. Abdullah Saeed, salah seorang akademisi Muslim terkemuka di Australia, dalam Islam in Australia (2003), mengemukakan, satu hal yang mempertemukan Muslim di berbagai belahan 
dunia adalah common values, nilai-nilai bersama yang bersifat fundamental dan mengikat. Dalam buku yang lain, Interpreting the Qur'an, Abdullah Saeed menyebut nilai-nilai yang terkait dengan kewajiban absolut yang harus dipenuhi Muslim, yaitu obligatory values, yang sejatinya menyatukan Muslim yang meliputi sistem keyakinan (system of belief) dan sistem peribadatan yang ditekankan dalam al Qur'an (values related to devotional practices emphasized in the Qur'an).

Tetapi karena dalam beragama selalu ada proses konstruksi yang selalu mengait dengan konteks tempat dan waktu tertentu, maka perbedaan paham, tradisi, dan kepranataan tidak bisa dielakkan. Maka pada ranah ini wajar jika ekspresi Islam di Indonesia memiliki kekhasan yang membedakan dengan ekspresi Islam, misalnya dengan di dunia Arab. Dari proses ini, pada gilirannya secara sosio-historis seharusnya terwujud suatu realitas, alih-alih Islam di Indonesia, tetapi Islam Indonesia.

Dua frase, Islam di Indonesia dan Islam Indonesia memiliki makna berbeda. Frase pertama mengindasikan Indonesia hanya tempat bagi Islam, sementara frase kedua, Islam Indonesia, mengindasikan adanya saling kemelekatan antara Islam dengan Indonesia. Dengan kemelekatan, maka seharusnya tidak perlu terjadi pertentangan antara Islam terutama dengan pilar-pilar kehidupan berbangsa dan bernegara, misalnya Pancasila dan bentuk negara. Praktik baik kemelekatan, sekedar contoh, dilakukan oleh Muhammadiyah yang memertegas pengakuan terhadap Pancasila dan bentuk negara dengan mengeluarkan dokumen pada Muktamar ke-47 di Makassar, Negara Pancasila sebagai Darul Ahdi wa Syahadah.

Masalahnya masih ada saja segelintir dari kalangan Islam, baik secara individual maupun berjejaring, yang merasa belum at home dengan Indonesia yang diperlihatkan dengan mengusung agenda, baik sporadis maupun sistematis, ideologi dan bentuk negara yang didaku lebih absah secara teologis. Khilafah seperti pernah diusung oleh Hizbut Tahrir Indonesia (Syamsul Arifin, 2010) dan beberapa gelintir kelompok lainnya, didaku paling Islami. Tidak sebatas di tataran wacana, bahkan diperkuat dengan aksi-aksi yang cenderung lekat dengan kekerasan. Fenomena infiltrasi paham dan radikalisme perlu terus diwaspadai mengingat sudah meluas hingga ruang virtual yang sulit dideteksi. Seiring menguatnya digitalisasi, ketertarikan dan keterlibatan (engagement) terhadap paham dan gerakan bisa dilakukan secara individual dan lebih senyap. Belakangan kita sering dikejutkan oleh aksi radikal yang dilakukan secara individual (lone wolf). Setelah ditelusuri, aksi tersebut dilakukan setelah 
menjelajah laman di dunia maya yang bermuatan radikalisme. Akibat dari serangkaian aksi ini, citra Islam mulai bergeser dari yang semula moderat ke radikal.

Infiltrasi paham radikalisme, belum lagi persoalan laten yang acapkali menjadi fenomena manifes jika ada pemicunya, yakni perbedaan paham keagamaan (ikhtilaf) antar-kelompok keagamaan pada Muslim di Indonesia yang mengarah pada perpecahan (iftiraq) yang dipicu antara lain oleh kontestasi dalam politik elektoral seperti yang terjadi belakangan ini, tak pelak menggerus modal sosial dan menyulitkan Muslim di Indonesia melakukan konsolidasi untuk memerkuat posisi strategis sebagai mayoritas.

Kebesaran dari sisi jumlah, tetapi jika gagal melakukan konsolidasi, Muslim di Indonesia bisa terjatuh pada kepingan-kepingan yang justru membenarkan tesis lama seperti diungkap oleh Jalaluddin Rakhmat (1986), "Riwayat Islam di Indonesia adalah riwayat ummat yang selalu berhimpun untuk berpecah.” Padahal, pada saat Muslim di kawasan dunia lain tercabik-cabik pasca-The Arab Spring, Islam Indonesia memiliki momentum mengaktulisasikan peran strategisnya.

Kebesaran dari sisi jumlah serta karakteristik Islam sebagai agama moderat perlu diapresiasi sebagai modalitas dalam mendinamisasi demokrasi di Indoneslia. Dengan wataknya yang moderat, Islam lewat konstruksi Muslim di Indonesia terutama oleh kalangan intelektualnya, mudah menerima demokrasi kendati kalau dirunut dari perkembangan Islam paling dini, demokrasi tidak ditemukan dalam leksikon politik Islam. Pada umumnya kalangan intelektual Muslim di Indonesia menghasilkan suatu konstruksi pemikiran yang disebut M. Syafi'i Anwar (1995) dengan substantivistik, yang dalam relasinya dengan politik lebih menekankan manifestasi substansial dari nilai-nilai Islam (Islamic injuctions). Konstruksi yang bercorak substantivistik tidak berarti menegasikan "Islamisasi”. Gagasan "Islamisasi” menurut Abdurrahman Wahid (2018), salah satu intelektual Muslim di Indonesia yang beraliran substantivistik sebagaimana disebut juga Greg Barton (1995), Fachry Ali dan Bahtiar Effendy (1986), Luthfi Assyaukanie (2011), dan Carool Kersten (2015), tetap diterima sebagai strategi menciptakan apa yang disebut dengan "masyarakat Islam” di Indonesia, daripada sebagai satu-satunya sistem alternatif yang menegasikan sistem-sistem lainnya. Karena demokrasi telah diterima baik sebagai fakta sejarah, apalagi secara normatif-teologis Islam dan demokrasi tidak dalam relasi yang saling berhadaphadapan, melainkan saling mengisi, maka seperti ditegaskan oleh Syafii Maarif, 
sistem politik demokrasi lebih dekat dengan cita-cita politik Qur'ani karena dalam demokrasi secara substansial terdapat mekanisme syura yang merupakan gagasan politik utama dalam al Qur'an (M. Syafi'i Anwar, 1995), sebagaimana juga dipertegas oleh Amien Rais bahwa demokrasi adalah paling cocok dengan semangat dan substansi al Qur'an dan Sunnah Nabi (Fachry Ali \& Bahtiar Effendy, 1986).

\section{Penutup}

Dengan membuka kembali kajian terdahulu dan mengutip sebagian intelektual dari kalangan Islam, sekedar ingin memperkuat tesis keberterimaan Islam terhadap demokrasi yang dipegang oleh sebagian besar Muslim di Indonesia, sehingga tidak cukup beralasan jika Islam diletakkan dalam posisi yang saling berhadapan dengan demokrasi. Kembali ke landasan normatif demokrasi yang berlaku secara universal, sebagaimana dikemukakan antara lain oleh Larry Diamond yang telah dikutip di atas, gerakan Islam kekinian yang antara lain mengambil pola populisme sebaiknya tetap dalam bingkai demokrasi. Diskursus populis yang diusung oleh elite harus terarah dalam upaya memberikan kesadaran kepada publik bahwa agenda-agenda utama reformasi seperti penegakan hukum, hak asasi manusia, pemberantasan korupsi, pemberdayaan ekonomi rakyat. Sejauh ini diskursus populis beserta aksi turunanya masih terperangkap pada isu-isu primordialistik yang acapkali muncul dalam kontestasi politik elektoral. Jika masih terperangkap dengan isu-isu demikian, maka wajar jika muncul kekhawatiran populisme Islam akan menjadi ancaman bagi demokrasi. 


\section{Daftar Pustaka}

Ali, Fachry dan Effendy, Bahtiar, Merambah Jalan Baru Islam: Rekonstruksi Pemikiran Islam Indonesia Masa Orde Baru, Bandung: Mizan, 1986.

Ambardi, Kuskridho, Mengungkap Politik Kartel: Studi Tentang Sistem Kepartaian di Indonesia Era Reformasi, Jakarta: Gramedia, 2009.

Anwar, M. Syafi'i, Pemikiran dan Aksi Islam Indonesia: Sebuah Kajian Politik Tentang Cendekiawan Muslim Orde Baru, Jakarta: Paramadina, 1995.

Appiah, Kwame Anthony, The Lies That Bind: Rethinking Identity, USA: Profile Books, 2018.

Arifin, Syamsul, Ideologi dan Praksis Gerakan Sosial Kaum Fundamentalis: Pengalaman Hizb al Tahrir Indonesia, Malang: UMM Press, 2010.

Arifin, Syamsul, Studi Islam Kontemporer: Arus Radikalisasi dan Multikulturalisme di Indonesia, Malang: Intrans Publishing, 2015.

Aspinall, Edward dan Sukmajati, Mada (ed.), Politik Uang di Indonesia: Patronase dan Klientelisme pada Pemilu Legislatif 2014, Yogyakarta: PolGov, 2015.

Assyaukanie, Luthfi, Ideologi Islam dan Utopia, Jakarta: Freedom Institute, 2011.

Azra, Azyumardi, Jaringan Ulama Timur Tengah dan Kepulauan Nusantara Abad XVII dan XVIII: Melacak Akar-akar Pembaharuan Pemikiran Islam di Indonesia, Bandung: Mizan, 1994.

Azra, Azyumardi, "Pengantar Ahli: Populisme, Politik Identitas, dan Demokrasi Indonesia" dalam Muhtadi, Burhanuddin, Populisme Populitik Identitas \& Dinamika Elektoral: Mengurai Jalan Panjang Demokrasi Prosedural, Malang: Intrans Publishing, 2019.

Barton, Greg, Gagasan Islam Liberal di Indonesia: Pemikiran Neo-Modernisme Nurcholish Madjid, Djohan Effendi, Ahmad Wahib dan Abdurrahman Wahid, Jakarta: Paramadina, 1999. 
Cannovan, Margaret, Populism, USAS: Harcourt Brace Jovanovich, Inc,1981

Dasandi, Niheer, Is Democracy Failing? A Primer for the $21^{\text {st }}$ Century, London: Themes \& Hudson, 2018.

Diamond, Larry, Developing Democracy: Toward Consolidation, Yogyakarta: Ire Press, 2003.

Eko, Sutoro, "Pengantar: Pelajaran Konsolidasi Demokrasi untuk Indonesia" dalam Larry Diamond, Developing Democracy: Toward Consolidation, Yogyakarta: Ire Press, 2003.

Emmerson, Donald K., Indonesia Beyond Soeharto: Negara, Ekonomi, Masyarakat, Transisi, Jakarta: Gramedia, 2001.

Fukuyama, Francis, Political Order and Political Decay: From the Industrial Revolution to the Globalization of Democracy, New York: Farrar, Straus and Giroux, 2014

Fukuyama, Francis, Identity, USA: Profile Books, 2018.

Gill, Graeme, The Dynamics of Democratization: Elites, Civil Society and the Transition Process, London: Macmillan, 2000.

Hadiz, Vedi R., Islamic Populism in Indonesia and the Middle East, Cambridge: Cambridge University Press, 2016.

Hadiz, Vedi R., Populisme Islam di Indonesia dan Timur Tengah, Jakarta: LP3ES, 2019.

Hasan, Zulkifli, "Pengantar" dalam Muhammad Najib, Jalan Demokrasi: Pengalaman Indonesia, Turki, dan Mesir, Jakarta: Republika, 2019.

Hefner, Robert W. (Ed.), Democratic Civility: The History and Cross-Cultural Possibility of a Modern Political Ideal, London: Roudledge, 2017.

Heywood, Andrew, Political Ideologies: An Introduction, London: Macmillan, 1992.

Jati, Wasisto Raharjo, "Trajektori Populisme Islam di Kalangan Kelas Menengah Muslim Indonesia”, Prisma, Vol. 36, No. 3, 2017.

Kamali, Mohammad Hashim, The Middle Path of Moderation in Islam: The Qur'anic Principle of Wasatiyyah, Oxford: Oxford University Press, 2015. 
Karni, Asrori S., Ed., Hajatan Demokrasi: Potret Jurnalistik Pemilu Langsung Simpul Islam Indonesia dari Moderat hingga Garis Keras, Jakarta: PT Era Media Informasi, 2006.

Kersten, Carool, Islam in Indonesia: The Contest for Society, Ideas and Values, London: Hurst \& Company, 2015.

Kusumo, Rangga dan Hurriyah, "Populisme Islam di Indonesia: Studi Kasus Aksi Bela Islam oleh GNPF-MUI Tahun 2016-2017”, Jurnal Politik, Vol. 4, No. 1, Agustus 2018.

MD, Moh. Mahfud, "Pengantar Ahli: Menyembuhkan Demokrasi Gagal” dalam Muhtadi, Burhanuddin, Populisme Populitik Identitas \& Dinamika Elektoral: Mengurai Jalan Panjang Demokrasi Prosedural, Malang: Intrans Publishing, 2019.

Muhtadi, Burhanuddin, Populisme Populitik Identitas \& Dinamika Elektoral: Mengurai jalan Panjang Demokrasi Prosedural, Malang: Intrans Publishing, 2019.

Muller, Jan-Werner, What is Populism?, UK: Penguin, 2016.

Oatey, Helen Spencer and Franklin, Peter Franklin, Intercultural Interaction: A Multidisciplinary Approach to Intercultural Coomunication, London: Palgrave Macmillan, 2009.

Qardhawi, Yusuf, Islam Jalan Tengah: Menjauhi Sikap Berlebihan dalam Beragama, Bandung: Mizan, 2017.

Rahmat, Jalaluddin, "Islam di Indonesia: Masalah Definisi" dalam M. Amien Rais (ed.), Islam di Indonesia: Suatu Ikhtiar Mengaca Diri, Jakarta: CV Rajawali, 1986.

Ramadan, Tariq, Islam: The Essentials, UK: Penguin, 2007.

Ramage, Douglas E., Politics in Indonesia: Democracy, Islam and the Ideology of Tolerance, London: Roudlage, 2005).

Robinson, Richard, Indonesia: The Rise of Capital, New South Wales: Allen \& Unwin Pty LTD, 1986.

Saeed, Abdullah, Islam in Australia,New South Wales: Allen \& Unwin, 2003.

Saeed, Abdullah, Interpreting The Qur'an, London: Roudlage, 2006 
Stockemer, Daniel [ed.] Populism Around the World: A Comparative Perspective, Switzerland: Springer, 2019.

Southwood, Julie and Flanagan, Patrick, Indonesia: Law, Propaganda and Teror, London: Zed Press, 1983.

Suseno, Fransz Magnis, "Demokrasi Indonesia dfalam Keadaan Bahaya!", dalam AE Priyono dan Usman Hamid (ed.), Merancang Arah Baru Demokrasi Indonesia Pasca-Reformasi, Jakarta: Kepustakaan Populer Gramedia Bekerja Sama dengan Public Virtue Institute, Hivos, dan yayasan TIFA, 2014.

Taggart, Paul, Populism, Buckingham: Open University Press, 2000.

Wahid, Abdurrahman, "Kelas Menengah Islam di Indonesia" dalam Richard Tanter dan Kenneth Young, Politik Kelas Menengah Indonesia, Jakarta: LP3ES, 2018. 